\title{
A brachiopod-dominated sea-floor assemblage from the Late Pliocene of the eastern Netherlands ${ }^{*}$
}

\section{F.P. Wesselingh ${ }^{1,{ }^{*}}$, W.J.M. Peters ${ }^{2}$ \& D.K. Munsterman ${ }^{3}$}

1 Naturalis Biodiversity Center, P.0. Box 9517, 2300 RA Leiden, the Netherlands

2 Hoeveweg 18, $6613 \mathrm{AE}$ Balgoy, the Netherlands

3 TNO Earth, Environment and Life Sciences (EELS), P.0. Box 80015, 3508 TA Utrecht, the Netherlands

* Corresponding author. Email: frank.wesselingh@naturalis.nl

Manuscript received: September 2012; accepted: May 2013

\section{Abstract}

A sea-floor assemblage from hardened sandstone boulders in which lingulid brachiopods predominate is recorded from the 0osterhout Formation near Balgoy (province of Gelderland, the Netherlands). Dinoflagellate cysts indicate a late Early-Late Pliocene (late Zanclean-Piacenzian) age of these boulders; the entire assemblage is indicative of clear marine waters near storm wave base along the southeastern margin of the North Sea Basin at the time. A possible commensal relationship between the lingulid brachiopods and the gastropod Calyptraea chinensis is implied.

Keywords: Calyptraea, Glottidia, dinoflagellate cysts, North Sea Basin, 0osterhout Formation, palaeoecology

\section{Introduction}

Shallow-marine lingulid brachiopod assemblages are well known from warm temperate and subtropical seas across the world (Williams et al., 2003 and references therein). In the North Sea Basin such assemblages commonly occur in Miocene strata. For example, various decalcified marine intervals within the Breda Formation in the southern and eastern Netherlands yield numerous phosphatic shells of lingulid brachiopods of the genus Glottidia. In general, associated aragonitic faunas are dissolved. Newly collected material from the vicinity of Nijmegen documents that such brachiopod-dominated associations extended well into the Pliocene. In the present paper we characterise this Pliocene brachiopod assemblage, analyse the associated aragonitic faunal elements and discuss the palaeoenvironmental implications.

\section{Material and methods}

The material studied occurs in boulders of a lithified sandstone matrix that have been dredged from the Loonse Waard near Balgoy (Fig. 1; compare Peters \& Wesselingh, 2009). At this locality, a variety of lithologies and faunas, representing different shallow-marine environments, have been recorded. Amongst these boulders, one lithology in particular stands out, namely that of fossiliferous, well-sorted, fine-grained quartzarenites, with a silty or clayey carbonate cement. Such samples are mostly yellowish grey in colour; they form the subject of the present note. We have analysed a total of 32 samples for lithology, fossil content and preservation signatures in order to characterise the fauna and reconstruct depositional environments. Four samples have been processed for palynological purposes at TNO (Utrecht) using traditional techniques, involving $\mathrm{HCl}, \mathrm{HF}$ digestion, no oxidation, ultrasonic bath, $15 \mu \mathrm{m}$ sieving and preparation of at least two residue slides mounted in glycerine jelly. Dinocyst taxonomy follows Fensome \& Williams (2004).

\footnotetext{
- In: Mulder, E.W.A., Jagt, J.W.M. \& Schulp, A.S. (eds): The Sunday's child of Dutch earth sciences - a tribute to Bert Boekschoten on the occasion of his 80 th birthday.
} 




Fig. 1. Sketch of Late Pliocene palaeogeography of the southern North Sea Basin and position of localities discussed in the present paper.

Samples have been dated by dinoflagellate cysts, with reference to key data conceming the marine palynostratigraphy of the Neogene to Early Pleistocene in the North Sea area (e.g., Louwye et al., 2004; De Schepper, 2006; Kuhlmann et al., 2006; De Schepper \& Head, 2009; De Schepper et al., 2009). Part of the material is in the collections of Naturalis Biodiversity Center; the remainder in the private collection of one of the authors (WJMP).

\section{Results}

\section{Lithology}

The grey to light yellow arenites are well lithified by interstitial clayey-silty carbonate cement. Inside, loosely organised clumps of mostly brachiopod (Fig. 2A) and molluscan shells, as well as serpulid tubes, balanid barnacles and bryozoans, are found. Aragonitic taxa occur in various states of dissolution, ranging from perfect preservation to entirely dissolved, commonly leaving an identifiable external mould (imprint). In general, both shells and moulds retain fine surface details. Variable amounts (in general low) of abraded shell fragments and shell grit occur. Both well-preserved fossils and grit are occasionally seen to be loosely grouped in poorly defined zones (of centimetre scale) that appear to be burrow fills (e.g., Fig. 2B). In a few places, including the interior of some valves, medium-sorted fine to medium-grained arenites occur (Fig. 2B, C). In two of the 32 samples, small zones with red limonitic staining have been noted. These glauconite-free sediments are representative of the 0osterhout Formation and are of a late Early-Late Pliocene age (see below). The Oosterhout Formation occurs in the subsurface of the Loonse Waard between 21.6 and $35 \mathrm{~m}$ below surface, as based on borehole $45 \mathrm{~F} 0144$ (coordinates: $x$ 176200; y 422560; +8.7 m NAP; see DinoData, 2012). The top of the underlying Breda Formation is equivalent to the Kattendijk Formation in northwest Belgium (Antwerp area) which has never been dated younger than early Zanclean. Moreover, in contrast to the Breda Formation, the Oosterhout Formation is generally rich in molluscs. Dredging near Balgoy reached depths of about 30 metres (Peters \& Wesselingh, 2009).

\section{Fossil content, palaeoenvironment and age}

The dinoflagellate cyst association is well preserved and moderately diverse (Table 1). The dominant genus is Spiniferites (40-58\% of dinocyst abundance), which is indicative of openmarine conditions. Several genera, including Heteraulacacysta and Paralecaniella, may also refer to a restricted marine palaeoenvironment (Louwye et al., 2010). Abundant spores and pollen ( $>50 \%$ of the total sum of dinocysts and sporomorphs) indicate a near-coastal setting. The overall microflora represents temperate sea surface temperatures. About $10 \%$ of the species are considered to be (sub)arctic and 5\% (sub)tropical (see Kuhlmann, 2004, for dinoflagellate cysts environmental proxies).

Based on the last occurrence datums (LODs) of Achomosphaera andalousiensis suttonensis, Barssidinium graminosum, $B$. pliocenicum and Melitasphaeridium choanophorum, the youngest (top) age is assumed to be (early) Piacenzian. According to Head (1998), the LODs of A. andalousiensis suttonensis and $M$. choanophorum are within the early Piacenzian ( $3.6-3.4 \mathrm{Ma})$. Louwye et al. (2004) recorded A. andalousiensis suttonensis from the Oorderen Sands Member and also documented the LOD of $M$. choanophorum to be within the Kruisschans Member in northwest Belgium. Kuhlmann et al. (2006) noted that the LOD of Barssidinium spp. fell within the Piacenzian (ca $2.6 \mathrm{Ma}$ ), while De Schepper et al. (2009) recorded the LODs of Barssidinium graminosum, B. pliocenicum and Melitasphaeridium choanophorum to predate ca $2.7 \mathrm{Ma}$. The first occurrence datums (FODs) of A. andalousiensis suttonensis and Desotodinium wrennii are within the 'Basal Shelly Unit' (Louwye et al., 2004), a unit that overlies the Kattendijk Formation (4.86-4.37/4.0 Ma). Marker species for the Kattendijk Formation, such as Reticulatosphaera actinocoronata, are absent. Hence, the age of the present microflora is taken to be late Zanclean to (early) Piacenzian. 


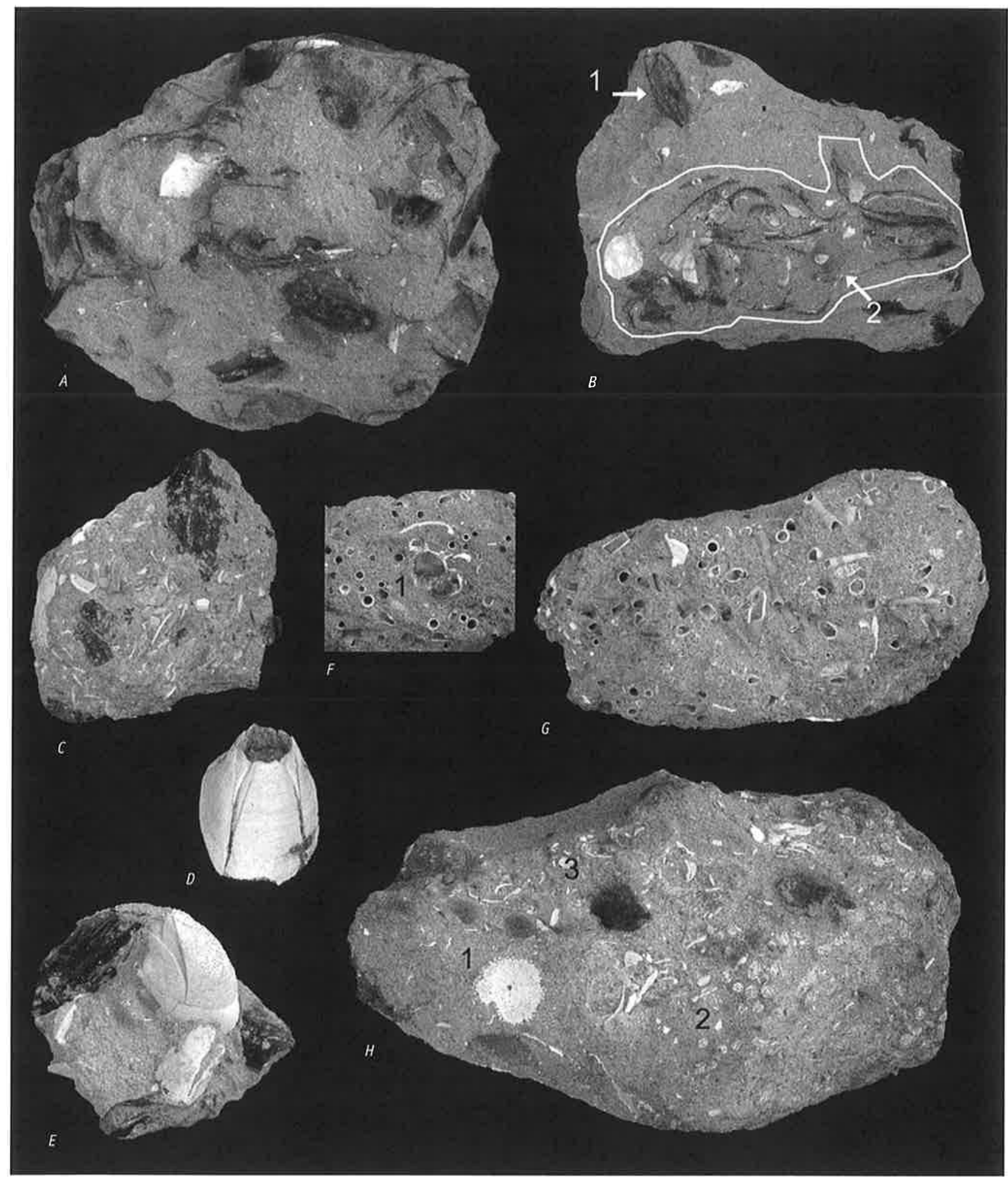

Fig. 2. Fossil concentrations from the yellowish-grey cemented quartzarenites of Balgoy. A, BG\#27, representative sediment block containing dispersed valves of Glottidia dumortieri (black) and shell fragments (length $83 \mathrm{~mm}$ ). B. BG\#21, block with concentration of shell fragments and fragmentary shells of Glottidia in burrow (line). Articulated Glottidia (1) and an external mould of Calyptraea chinensis (2) are also seen (length 69 mm). C. BG\#04, relatively densely packed, worn small shell fragments and some shells of Glottidia, possibly representing a burrow fill (height $36 \mathrm{~mm}$ ). D. BGH O6, unidentified balanid preserved in situ (length $14.2 \mathrm{~mm}$ ). E. Unidentified balanids preserved in situ; the lower-right specimen is attached to an articulated shell of Glottidia (width of barnacle $31.2 \mathrm{~mm}$ ). F. BG\#19, piece packed with Ditrupa arietina and basal view of articulated unidentified barnacles (width of view $19 \mathrm{~mm}$ ). G. BG\#19, piece packed with Ditrupa arietina (length $42.6 \mathrm{~cm}$ ). H. BG\#23, block packed with bryozoans (Cupuladria sp.) (1) and unidentified colonial bryozoans (2) and burrow (3) filled with relatively coarse-grained sand and abraded shell fragments (length $67 \mathrm{~mm}$ ). Material housed in collection of second author. 
Table 1.

\begin{tabular}{|c|c|c|c|c|c|}
\hline & & $1 \mathrm{~A}$ & $2 \mathrm{~A}$ & $3 \mathbf{A}$ & $4 \mathrm{~A}$ \\
\hline Acritarchs & $\mathrm{MF}$ & & & 42 & 43 \\
\hline Botryococcus & MF & 1 & 1 & & 2 \\
\hline Gymatiosphaera spp. & MF & 2 & & & \\
\hline Foraminiferal test lining & MF & 2 & & 3 & 2 \\
\hline Paralecaniella spp. & MF & 1 & & & \\
\hline Waaslandia geminifera & $\mathrm{MF}$ & 1 & & & \\
\hline Zygnemataceae & MF & & 1 & & \\
\hline Achomosphaera andalousiensis & $\mathrm{DC}$ & 2 & 1 & 4 & 2 \\
\hline Achomosphaera andalousiensis suttonensis & & & & 2 & \\
\hline Achomosphaera spp. & $\mathrm{DC}$ & & 1 & & 1 \\
\hline Algidasphaeridium euaxum & $\mathrm{DC}$ & 1 & & & \\
\hline Algidasphaeridium spp. & $\mathrm{DC}$ & 3 & 1 & 1 & \\
\hline Amiculosphaera umbraculum & $\mathrm{DC}$ & & & & 2 \\
\hline Ataxiodinium choane & $\mathrm{DC}$ & & & & 1 \\
\hline Ataxiodinium spp. & $\mathrm{DC}$ & 1 & & & \\
\hline Barssidinium graminosum & $\mathrm{DC}$ & 1 & & 3 & 5 \\
\hline Barssidinium pliocenicum & $\mathrm{DC}$ & 1 & 1 & 2 & 1 \\
\hline Batiacasphaera sphaerica & $\mathrm{DC}$ & 1 & 1 & & \\
\hline Bitectatodinium/Filisphaera complex & $\mathrm{DC}$ & 2 & 2 & & \\
\hline Bitectatodinium spp. & $\mathrm{DC}$ & & 2 & & \\
\hline Bitectatodinium tepikiense & $\mathrm{DC}$ & 1 & & 1 & 1 \\
\hline Cristadinium spp. & $\mathrm{DC}$ & & 1 & & \\
\hline Desotodinium wrennii & $\mathrm{DC}$ & & & 1 & \\
\hline Filisphaera spp. & $\mathrm{DC}$ & 1 & & & \\
\hline Habibacysta tectata & $\mathrm{DC}$ & 4 & 2 & 1 & 1 \\
\hline Heteraulacacysta spp. & $\mathrm{DC}$ & 8 & 1 & 9 & 7 \\
\hline Hystrichostrogylon spp. & $\mathrm{DC}$ & & 1 & & \\
\hline Impagidinium spp. & $\mathrm{DC}$ & 1 & 1 & 1 & \\
\hline Lejeunecysta catomus & $\mathrm{DC}$ & & & 2 & 1 \\
\hline Lingulodinium machaerophorum & $\mathrm{DC}$ & & & 1 & \\
\hline Lejeunecysta spp. & $\mathrm{DC}$ & 1 & & & \\
\hline Melitasphaeridium spp. & $\mathrm{DC}$ & & 1 & & 1 \\
\hline Melitasphaeridium choanophorum & $\mathrm{DC}$ & & & & 2 \\
\hline Operculodinium centrocarpum & $\mathrm{DC}$ & 1 & 1 & 5 & 1 \\
\hline Operculodinium centrocarpum sensu & $\mathrm{DC}$ & 4 & 2 & 4 & 7 \\
\hline \multicolumn{6}{|l|}{ Wall \& Dale (1966) } \\
\hline Operculodinium israelianum & $\mathrm{DC}$ & 1 & & & 1 \\
\hline Operculodinium spp. & $\mathrm{DC}$ & 1 & & & \\
\hline Polysphaeridium zoharyi & $\mathrm{DC}$ & & & 1 & \\
\hline Selenopemphix brevispinosa & $\mathrm{DC}$ & 3 & 4 & 9 & 5 \\
\hline Selenopemhix dionaeacysta & $\mathrm{DC}$ & & & 4 & 2 \\
\hline Selenopemphix quanta & $\mathrm{DC}$ & 2 & 1 & 4 & 1 \\
\hline Selenopemphix spp. & $\mathrm{DC}$ & 1 & 1 & & \\
\hline Spiniferites membranaceus & $\mathrm{DC}$ & & 1 & & \\
\hline Spiniferites mirabilis/hyperacanthus & $\mathrm{DC}$ & & & 4 & 2 \\
\hline Spiniferites spp. & $\mathrm{DC}$ & 54 & 18 & 63 & 64 \\
\hline Tectatodinium pellitum & $\mathrm{DC}$ & & & 2 & \\
\hline Trinovantedinium capitatum & $\mathrm{DC}$ & 1 & & & \\
\hline Trinovantedinium spp. & $\mathrm{DC}$ & & 1 & 1 & 1 \\
\hline Tuberculodinium vancampoae & DC & & & & 2 \\
\hline Bisaccates & SP & 58 & 21 & 50 & 97 \\
\hline Sporomorphs (excl. bisaccates) & SP & 50 & 82 & 32 & 55 \\
\hline
\end{tabular}

The benthic macrofauna is dominated by the lingulid brachiopod Glottidia dumortieri and the serpulid Ditrupa arietina. Various other gastropod and bivalve taxa occur as well (Fig. 2; Table 2). Balanid barnacles, colonial cheilostome bryozoans, wood fragments and rare carapaces of decapod crustaceans have also been noted. None of the molluscan species is particularly common, but taxa found in most blocks include the gastropod Calyptraea chinensis and the bivalves Atrina fragilis (s. lat.) and Varicorbula gibba. The presence of Nassarius spectabilis vandewouweri, which is known from the early Piacenzian Luchtbal Member and basal part of the 0orderen Member in the Antwerp area (northwest Belgium), coupled with the absence of Palliolum gerardi (which ranges into the Luchtbal Member, but not higher), suggests an early to middle Piacenzian date. The yellow sandstones described here differ from the highly fossiliferous limonitic sandstones that are found at Balgoy; these contain at least four species that are indicative of an Early Pliocene age (Peters \& Wesselingh, 2009).

Most fossils either float or are loosely arranged in poorly defined clumps of up to $1.5 \mathrm{~cm}$ length (Fig. 2B, C). The majority of shells of Glottidia and bivalves are single valves, but (semi-) articulated individuals are not rare either. In three instances, articulated balanid cirripedes have been encountered (Fig. 2D-F). No apparent predominant orientation of fossils has been observed. This preservation signature is characteristic of seafloors at or below storm wave base, with moderate to strong bioturbation. In two blocks, large numbers of tubes of Ditrupa (Fig. 2F, G) have been noted; these appear to have either a random or clumpy orientation. Such associations are known from modern-day Ditrupa banks of the northwest Mediterranean (Grémare et al., 1998); similar examples have been recorded for Pliocene strata at Mill-Langenboom (province of NoordBrabant; see Wijnker et al., 2008; Peters, 2013). The absence of significant signs of wear and abrasion on much of the fossil material is indicative of little physical reworking. However, in many of the blocks, strongly worn and discoloured fine shell gravel and fragments have been noted, mostly occurring at random but also in clumps inside burrow outlines (Fig. 2C). This suggests either the presence of tempestites that were bioturbated post-depositionally or a phase of reworking from an underlying lag deposit that we have not yet identified in the material available. Lag deposits containing an admixture of both well-preserved and abraded fossils are known from the Pliocene, e.g., at the nearby Mill-Langenboom locality (Wijnker et al., 2008; Peters, 2013).

The predominance of filter feeders (Glottidia, Ditrupa, barnacles) in these faunas implies that the waters must have been relatively clear (Fig. 3); Atrina fragilis is often associated with sea grass habitats. The lack of extensive storm reworking would suggest a depositional environment around storm wave base, which could be typically at water depths of around $20 \mathrm{~m}$. Today, Ditrupa banks occur at similar depths in the Mediterranean (Grémare et al., 1998). Lingulid brachiopod 
Table 2. Benthic macrofossil taxa from Balgoy. Valves of bivalve taxa are counted as half a specimen, numbers are converted to the next full number. @ stands for poorly preserved (abraded) and discoloured specimens that are likely to have been reworked. Nassarius s. vanderwouweri = Nassarius spectabilis vanderwouweri.

B1 B2 B3 B4 B5 B6 B7 B8 B9 B10 B11 B12 B13 B14 B15 B16 B17 B18 B19 B20 B21 B22 B23 B24 B25 B26 B27 B28 B29 B30

\section{Glottidia dumortieri}

Ditrupa arietina

Unidentified barnacles

Unidentified bryozoans

Wood fragments

Unidentified decapods

Nucula trigonula

Nucula cf. nucleus

Yoldia semistriata

Atrina fragilis s. lat.

Pectinidae indet.

Aequipecten opercularis

Heteranomia squamula

Monia patelliformis

Diplodonta rotundata

Laevicardium decorticatum

Ensis sp. indet.

Ensis hausmanni

Cultellus cultellatus

Tellina s. lat. indet.

Dosina lentiformis

Venerupis sp. indet.

Varicorbula gibba

Lentidium complanatum

Teredo sp. indet.

Cingula inusitata

?Petaloconchus glomeratus

Naticidae indet.

Calyptraea chinensis

Capulus cf. ungaricus

Aporrhais scaldensis

Amyclina labiosa

Nassarius s. vanderwouweri

$\begin{array}{rrrrrrrrrrrrr}4 & 1 & 9 & 2 & 5 & 1 & 127 & 14 & 6 & 4 & 11 & 4 & 13 \\ & 7 & & 1 & & & & 2 & 2 & & 3 & 1 \\ & & & & 1 & & & & & 6 & & 3 \\ & & & & & & & & & & & \\ 1 & & & & & & & 1 & 1 & & & \\ & & & & & & 1 & 1 & & 2 & 1 & & \end{array}$

1

1

1

11

@

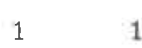

1

1

1

1

1
1

1

$\begin{array}{cccccccccccccc}11 & 24 & & 12 & 22 & 24 & & 17 & 11 & 9 & 29 & 25 & 2 & 14 \\ & 1 & 2 & & 5 & 3 & 4 & 2 & 4 & 1 & 1 & 4 & & 1 \\ & & 3 & 2 & 1 & 1 & 3 & & & & & 1 & 3 & 2 \\ & & & & & & 6 & & & & & & & \\ & & & & & & & & & & & & & \end{array}$

1

11

1

11

111

@

11

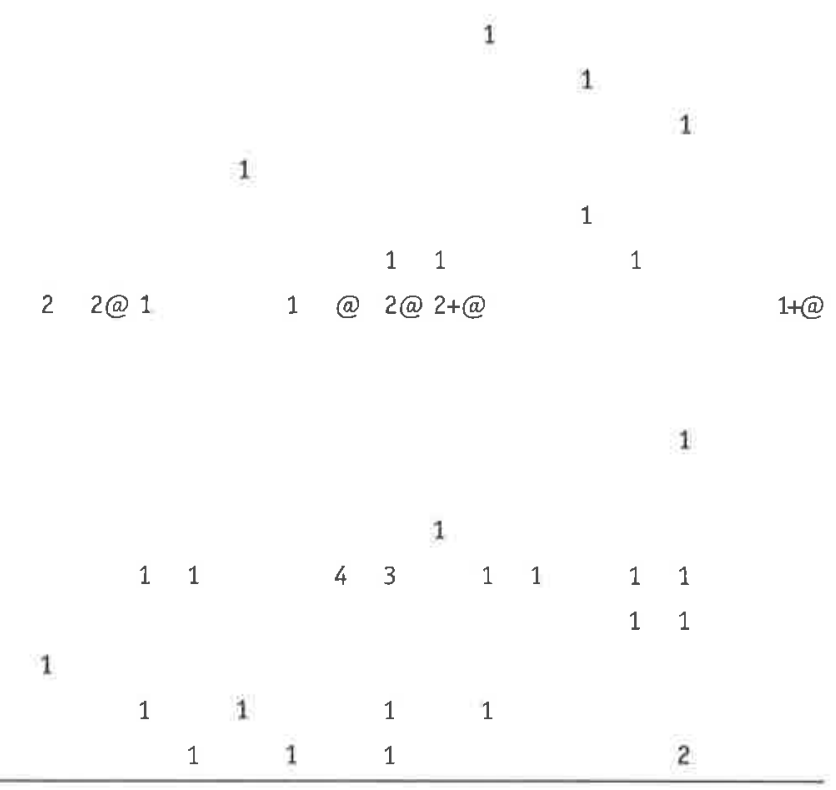

associations are often found in restricted marine settings; however, we have not found any indication of lowered salinities or turbidity in the molluscan fauna which comprises only stenohaline taxa. Thus, these lingulid-bearing calcareous quartzarenites must have been laid down under open-marine, clear-water conditions around storm wave base.

\section{Discussion and concluding remarks}

The fauna described here is of an age that is similar to several other localities in the southern North Sea Basin (Fig. 1), such as Delden (Oosterhout Formation; see Bosch \& Wesselingh, 2006), Mill-Langenboom (same unit; Wijnker et al., 2008; Peters, 2013) and the Antwerp area in northwest Belgium (Luchtbal

Fig. 3. Artist's impression of the early Piacenzian sea floor at Balgoy. 
Member; Marquet \& Landau, 2006). The Balgoy and Luchtbal faunas are indicative of clear-water settings; the latter has yielded an abundance of bryozoan and algal species as well as epifaunal and semi-infaunal temperate molluscan taxa (e.g., Marquet \& Landau, 2006). The Mill-Langenboom locality documents a predominance of semi-infaunal and infaunal warm temperate taxa and mostly represents sea-floor conditions above storm wave base in an open embayment which whales frequented (Peters, 2013). At Delden, exclusively the deep infaunal portion of the fauna appears to have been preserved; conditions of deposition are incompletely known. Localities within the southern North Sea Basin of early Piacenzian age point to the common occurrence of relatively clear-water settings. The Rhine and Meuse (Maas) rivers must have contributed comparatively small sediment loads at the time. Further north, a major river system (from the east), the Eridanos River (Overeem et al., 2002; Kuhlmann et al., 2006), apparently did not smother the southern embayment of the North Sea with sediments.

The relatively common occurrence of Calyptraea chinensis in the Balgoy material is remarkable. This species is not uncommon in shallow-marine Pliocene intervals within the southern North Sea Basin, but it is never abundant. However, in the fauna studied here, it is the commonest gastropod. In several of the blocks we have observed shells (or external moulds of shells) attached to valves of Glottidia. A comparable attachment of calyptraeid gastropods to living lingulid brachiopods was recorded from Cebu, the Philippines, by Savazzi (1991), who proposed a possibly commensal relationship between these taxa. Such commensalism might explain the relative abundance of Calyptraea in the Balgoy fauna.

The newly recorded faunal association from Balgoy extends the occurrence of brachiopod-dominated associations in the North Sea Basin well into the late Early to Late Pliocene, occurring in relatively clear, warm-temperate waters at or just above storm wave base.

\section{Acknowledgements}

We thank Nico M.M. Janssen (Utrecht) for palynological preparation of samples and Steve K. Donovan (Leiden), Stijn De Schepper (Bergen, Norway) and Noël Vandenberghe (Leuven) for insightful comments on an earlier version of the typescript.

\section{References}

Bosch, J. \& Wesselingh, F.P., 2006. On the stratigraphic position of the Delder Member (Breda Formation, 0verijssel, the Netherlands) with implications for the taxonomy of Pygocardia (Mollusca, Bivalvia). Cainozoic Research 4: 109-117.

De Schepper, S., 2006. Plio-Pleistocene dinoflagellate cyst biostratigraphy and palaeoecology of the eastern North Atlantic and southern North Sea Basin. Unpubl. PhD thesis, University of Cambridge, 327 pp.
De Schepper, S. \& Head, M.J., 2009. Pliocene and Pleistocene zonation of DSDP Hole 610A, eastern North Atlantic. Palynology 33: 179-218.

De Schepper, S., Head, M.J. \& Louwye, S., 2009. Pliocene dinoflagellate cyst stratigraphy, palaeoecology and sequence stratigraphy of the Tunnel-Canal Dock, Belgium. Geological Magazine 146: 92-112.

DinoData, 2012; www.dinoloket.nl (accessed February 2012).

Fensome, R.A. \& Williams, G.L., 2004. The Lentin and Williams index of fossil dinoflagellates, 2004 edition. American Association of Stratigraphic Palynologists, Contributions Series 42: 1-909.

Grémare, A., Sardá, R., Medernach, L., Jordana, E., Pinedo, S., Amouroux, J.M., Martin, D., Nozais, C. \& Charles, F., 1998. On the dramatic increase of Ditrupa arietina 0.F. Müller (Annelida, Polychaeta) along both the French and Spanish Catalan coasts. Estuarine, Coastal and Shelf Science 47: 447-457.

Head, M.J., 1998. Marine environmental change in the Pliocene and early Pleistocene of eastern England: the dinoflagellate evidence reviewed. In: Van Kolfschoten, T. \& Gibbard, P.L. (eds): The dawn of the Quaternary. Mededelingen NITG TNO 60: 199-226.

Kuhlmann, G., 2004. High resolution stratigraphy and paleoenvironmental changes in the southern North Sea during the Neogene. Unpubl. PhD thesis, Universiteit Utrecht, $205 \mathrm{pp}$.

Kuhlmann, G., Langereis, C.G., Munsterman, D., Van Leeuwen, R.-J., Verreussel, R., Meulenkamp, J.E. \& Wong, T.E., 2005. Chronostratigraphy of Late Neogene sedimnts in the southern North Sea Basin and palaeoenvironmental interpretations. Palaeogeography, Palaeoclimatology, Palaeoecology 239: 426-455.

Louwye, S., Head, M.J. \& De Schepper, S., 2004. Dinoflagellate cyst stratigraphy and palaeoecology of the Pliocene in northern Belgium, south North Sea Basin. Geological Magazine 143: 353-378.

Louwye, S., Marquet, R., Bosselaers, M. \& Lambert, 0., 2010. Stratigraphy of an Early-Middle Miocene sequence near Antwerp in northern Belgium (southern North Sea Basin). Geologica Belgica 13: 269-284.

Marquet, R. \& Landau, B., 2006. The gastropod fauna of the Luchtbal Sand Member (Lillo Formation, Farly Pliocene) of the Antwerp region (Belgium). Cainozoic Research 5: 13-49.

Overeem, I., Weltje, G.J., Bishop-Kay, C. \& Kroonenberg, S.B., 2002. The Late Cenozoic Eridanos system in the southern North Sea Basin: a climate signal in sediment supply? Basin Research 13: 293-312.

Peters, N., 2013. Van reuzenhaai tot Chalicotherium. Boxtel, Dertijdmuseum De Groene Poort, $160 \mathrm{pp}$.

Peters, W.J.M. \& Wesselingh, F.P., 2009. Balgoy: een nieuwe Plioceen vindplats voor Nederland met implicaties voor de pliocene mollusken zonering van het Noordzeebekken. Afzettingen WTKG 30: 12-18.

Savazzi, E., 1991. Burrowing in the inarticulate brachiopod Lingulo anatina. Palaeogeography, Palaeoclimatology, Palaeoecology 85: 101-106.

Wijnker, E., Bor, T.J., Wesselingh, F.P., Munsterman, D. K., Brinkhuis, H., Burger, A.W., Vonhof, H.B., Post, K., Hoedemakers, C., Janse, A.C. \& Taverne, N., 2008. Neogene stratigraphy of the Langenboom locality (Noord-Brabant, the Netherlands). Netherlands Journal of Geosciences 87: 165-180.

Williams, A., Cohen, B.L., Cusack, M. \& Long, S.L., 2003. Provenance of Atlantic lingulid brachiopods. Palaeontology 43: 999-1018. 